\title{
The Effects of Local Banking Market Structure on the Bank-Lending Channel of Monetary Policy
}

\author{
Robert M. Adams and Dean F. Amel*
}

February 10, 2005

\begin{abstract}
$\underline{\text { Abstract }}$
We study the relationship between banking competition and the transmission of monetary policy through the bank lending channel. Using business small loan origination data provided from the Community Reinvestment Act from 1996-2002 in our analysis, we are able to reaffirm the existence of the bank lending channel of monetary transmission. Moreover, we find that the impact of monetary policy on loan originations is weaker in more concentrated markets. (JEL E44, E52, G32, L1)
\end{abstract}

* Division of Research and Statistics, Board of Governors of the Federal Reserve System, Washington, D.C. 20551. The views expressed here are those of the authors and do not necessarily reflect those of the Board of Governors or its staff. We thank David Kite and Eli Mou for research assistance and Ben Bernanke, Ron Borzekowski, Ken Brevoort, Andrew Cohen, William English, Elizabeth Kiser, Myron Kwast, Fabio Natalucci, Róisín O’Sullivan, Robin Prager, and participants in a Federal Reserve Board workshop and a session at the 2005 ASSA Convention for comments on a previous draft. Any remaining errors are the responsibility of the authors. 


\section{$\underline{\text { Introduction }}$}

In the last two decades, considerable research has focused on monetary policy transmission mechanisms in an effort to better understand how monetary policy affects the real economy. One focal point of this research has been the role of the banking industry in the transmission of monetary policy, including the effect of monetary policy on bank lending. The traditional monetary (or interest rate) transmission channel focuses on the effect of monetary policy on interest rates and through interest rates on lending and credit. By contrast, the bank-lending channel of monetary policy focuses on the impact of monetary policy on the supply of bank loans. The bank-lending channel is most important in cases where borrowers do not have viable alternatives to bank loans as sources of funding. Most research on the bank-lending channel has concentrated on its existence, overall importance and on the types of banks where it is most likely to be observed. This work has attempted to measure the extent to which monetary policy is transmitted through banks to private-sector borrowing, and so spending, activity. ${ }^{1}$ Crosssectional work has examined how banks with different characteristics vary in their responsiveness to monetary policy stimuli. However, no research exists on the effect of local banking competition or other market characteristics on the sensitivity of bank lending to monetary policy. Assuming that monetary policy not only changes bank reserves (through open market operations or reserve requirements), but also changes a bank's marginal costs (by affecting rates paid on liabilities), competition is potentially important, because the degree of banking competition is a determinant of how marginal cost shocks are transmitted to prices and lending. ${ }^{2}$ This paper estimates the variability in the sensitivity of bank lending to changes in monetary policy as a result of differences in measures of competition in local banking markets.

There is a well established relationship between market structure and loan and deposit interest rates. Several articles have examined this relationship using the Structure-Conduct-Performance theory, which posits that greater market concentration

\footnotetext{
${ }^{1}$ The bank-lending channel is a complement to the balance-sheet channel, which posits that shifts in monetary policy affect loan demand. In the balance-sheet channel, monetary policy affects a firm's ability to raise funds, especially bank funding, because firms become more or less creditworthy. See Cecchetti (1996) for a description of these theories.

${ }^{2}$ Demand and cost functions also determine the extent to which marginal cost changes are reflected in prices.
} 
leads to less lending and higher loan rates. ${ }^{3}$ This paper blends this research with research on the transmission of monetary policy. Using data on the volume of small business loans originated each year, we are able to reaffirm the existence of the bank-lending channel and detect the dampening effect of market concentration on responses in loan activity to monetary policy. In particular, we find that as concentration increases, the sensitivity of bank lending to the federal funds rate (our monetary policy indicator) decreases. ${ }^{4}$ To the extent that monetary policy relies on the effectiveness and predictability of the bank-lending channel, monetary authorities have reason to be concerned with changes in banking market concentration.

Because the appropriate data are not readily available, research has tended to ignore the effects of local market characteristics, specifically of varying levels of local concentration in the banking industry, on the transmission of monetary policy. In this paper we use Community Reinvestment Act (CRA) data that allow us to investigate the relationship between banking industry competition - measured by local market concentration - and the effectiveness of monetary policy. This dataset also provides measures of new lending activity that are superior to those used in past research.

The CRA data annually measure the dollar volume of loan originations under $\$ 1$ million to all businesses and, separately, to only those businesses with less than $\$ 1$ million in revenue. CRA loan data are collected at the census tract level for all depository institutions, regardless of whether the lender has a branch presence in a nearby location. These data not only measure loan originations for standard business credit, they also include originations made by credit card lenders such as American Express, Discover, and banks with substantial business credit card programs such as Wells Fargo. Since CRA data measure loan originations, they are likely to reflect any effects of monetary policy on economic activity more accurately than the quarterly Call Report

\footnotetext{
${ }^{3}$ The literature has also noted a relationship between market structure and deposit rates. While this paper concentrates only on bank lending, our results could imply that banking competition also affects monetary policy through liquidity effects coming from deposit markets.

${ }^{4}$ This result is interesting in that it suggests that the existence of a market imperfection - namely, market power arising from concentration -- reduces the effectiveness of monetary policy, whereas most other research on monetary policy find that the stronger the market imperfection, the greater the effectiveness of the monetary policy instrument. See Bernanke, Gertler and Gilchrist (1999).
} 
data used by previous micro-level research on the bank-lending channel. Call Report data yield imperfect measures of the effect of monetary policy on bank lending, since they measure outstanding loans, which can be affected by loan purchases and sales, loan payoffs and other events unrelated to changes in loan originations. Hence, taking the difference in outstanding loans between successive Call Reports provides a relatively noisy measure of new loan activity compared to the CRA data employed here. ${ }^{5}$ The tradeoff for using the more accurate CRA data is that they are available less frequently, making it more difficult to track the speed of the response of loan activity to policy changes. In addition, the CRA data only cover seven years, so that our data reflect only one business cycle and may not be representative of the economy during previous or future cycles. ${ }^{6}$

The results of this study are important because small businesses comprise a substantial portion of the U.S. economy. Small business loans account for about 12 percent of total loans outstanding. ${ }^{7}$ Small businesses account for over 50 percent of private sector employment and 75 percent of net new jobs. ${ }^{8}$ Changes in small business financing caused by changes in monetary policy could have a significant effect on employment changes. Moreover, while we only have data for small business lending, there is no reason to think that competition would not have similar effects on the transmission of monetary policy in other local loan (and deposit) markets.

\section{$\underline{\text { Previous Research }}$}

Bernanke and Blinder (1988) provide a simple IS-LM based theoretical model of the bank lending channel, where banks rely on a single deposit source for funds. Romer and Romer (1990) fail to find support for the bank lending channel; they argue that banks

\footnotetext{
${ }^{5}$ We estimated several models using Call Report data that were similar in structure to previous research and were unable to confirm the existence of the bank-lending channel or the effect of competition on monetary policy.

${ }^{6}$ In order to address this shortcoming of the available data, we conduct a univariate analysis of single market banks using Call Report data from 1990 to 2003 that yields results consistent with those from our multivariate analysis of CRA data.

${ }^{7}$ These data are from the 2001-2003 June 30 Call Reports. Consumer lending accounts for about 15 percent of total loans outstanding and real estate loans account for about 35 to 40 percent of total loans. If we do not include real estate lending in the denominator, then small business lending accounts for 18 percent of loans outstanding.

${ }^{8}$ See The Small Business Economy. A Report to the President (2001).
} 
could shield themselves from Federal Reserve-induced changes in reserves by holding negotiable certificates of deposit with little or no reserve requirements. Stein (1998) counters with a model showing that the bank lending channel can still exist when banks have several sources of funding.

Bernanke and Blinder (1992) find a relationship between the federal funds rate and bank lending over and above the liquidity effects caused by changing interest rates, providing evidence that the bank-lending channel exists. Kashyap, Stein, and Wilcox (1993) find that changes in monetary policy lead to a shift in the mix of firms' external financing. They observe that tighter monetary policy leads to an increase in commercial paper issuance and a reduction in bank lending and argue that the spread between commercial paper and treasury bills is a proxy for the stance of monetary policy.

Kashyap and Stein (1997) and Cecchetti (1999) consider national concentration ratios in their analysis of the effectiveness of monetary policy in Europe. Both studies use three-firm and five-firm concentration ratios, not because they are related to competition, but because they are measures of bank size or of a banking system's reliance on reserves. Banks in nations with higher concentration measures (i.e., with a few banks controlling a large percentage of total banking assets) are less sensitive to reserve contractions, since they have access to alternative forms of financing.

Kashyap and Stein (2000) conduct an extensive analysis of the bank-lending channel for U.S. monetary policy. They use Call Report data on a very large panel data set of American banks over 1976-1993 to see if there are cross-sectional differences in the ways in which banks react to monetary policy shocks. They find that a bank-lending channel exists and that it is large enough to be of economic significance. Their results suggest that the channel works primarily through smaller banks that do not have access to alternative sources of funding in the money markets. The effect of monetary policy is stronger for commercial and industrial loans than for other types of bank lending.

In related research, Jayaratne and Morgan (2000) examine bank investment and cash flows to see if there is evidence of market imperfections that would give monetary policy scope to affect bank lending. Like Kashyap and Stein, they find that there are imperfections in markets for uninsured bank funds, and that these frictions are larger for 
smaller banks than for banks large enough to more easily use the capital markets as alternative sources of funds.

While both the Kashyap-Stein and Jayaratne-Morgan papers use panel data, both focus on firm-level effects of policy changes and neither paper attempts to control for differences in local banking markets that have been shown to affect bank lending. An extensive literature in industrial organization has examined whether banks in more concentrated markets tend to adjust prices less completely in response to changes in input costs than banks in markets with a more competitive structure. Hannan and Berger (1991) find that banks in more concentrated markets have more rigid deposit rates. They also find that deposit rates are stickier when they are moving upward than when they are declining. Neumark and Sharpe (1992) combine these results, finding that banks in more concentrated markets are slower to raise deposit rates and quicker to lower them when Treasury bill rates, a measure of input costs, change. They also find that banks in concentrated markets offer lower rates on deposits than banks in more atomistic markets. As is typical of cross-sectional research in banking, these authors define banking markets as geographically local, with metropolitan areas used to approximate urban markets and county boundaries used to delineate rural markets. These definitions are based on two sources of support. Survey evidence finds that both households and small businesses overwhelmingly use depository institutions located within a few miles of their homes or places of business as viable suppliers of many banking services. ${ }^{9}$ In addition, a great number of empirical studies of the determinants of bank pricing and profitability find that local market structure has a significant effect on bank behavior and performance. ${ }^{10}$

Kahn, Pennacchi and Sopranzetti (2001) examine cross-sectional differences in the behavior of rates for personal and automobile loans, and get very different results for the two types of loan. They find that interest rates for personal loans are stickier in more concentrated banking markets, while auto loan rates adjust more quickly in such markets.

\footnotetext{
${ }^{9}$ For households, see Amel and Starr-McCluer (2002), which examines evidence from the Survey of Consumer Finances. For small businesses, see Kwast, Starr-McCluer and Wolken (1997), which examines evidence from the Survey of Small Business Finances. While bank customers frequently state that they search for banking services within areas smaller than a metropolitan area or county, the overlap of the search areas of many bank customers is assumed to transmit competitive forces throughout an economically integrated local area. Geographic markets are defined by the extent to which market power cannot be curtailed by substitution to out-of-market competitors.

${ }^{10}$ See Group of Ten (2001), chapter V, for an overview of these studies.
} 
They attribute the difference to efficiency gains from scale economies in auto loan markets that are absent in markets for personal loans. ${ }^{11}$ The results from these studies imply that, in more concentrated markets, bank interest rates on loans exhibit partial and sticky reactions to changes in input costs (such as those caused by changes in monetary policy), potentially dampening the effectiveness of the bank-lending channel.

Research on monetary policy and bank competition in the European Monetary Union has found similar results. Lensink and Sterken (2002) recognize the relationship between monetary transmission and competition in their overview of the subject, but empirical studies using European data either confirm the existence of the bank-lending channel and find that it operates much as it does in the U.S. (Kakes and Sturm, 2002; and Altunbas, Fazylov, and Molyneux, 2002), or they confirm the price-concentration relationship in European banking markets (Corvoisier and Gropp, 2002; and Bikker and Haaf, 2002), but no study directly analyzes the relationship between the bank-lending channel and competition in Europe. ${ }^{12}$

Three additional papers that have examined the monetary transmission mechanism deserve mention. Peltzman (1969) pioneered this line of research. He developed a very parsimonious model that tied market structure to the transmission of monetary policy. Given the age of his work, he focused on structural factors that are no longer of importance. In addition, his geographic banking market definitions conflict with more recent empirical findings. Sellon (2002) does not perform a cross-sectional analysis, but his work is of interest because it shows that regulatory and technological changes over time have had a great effect on the speed of transmission of monetary policy. He finds that the response of interest rates to monetary policy has increased over time and that institutional changes have broadened the effects of policy changes. Finally, Cottarelli and Kourelis (1994) use an international sample to study differences in the speed of transmission. They find that entry barriers slow policy transmission, but they do

\footnotetext{
${ }^{11}$ An alternative explanation for the results for automobile-loan markets is that these markets are dominated by the captive-finance divisions of large automobile manufacturers, so that more concentrated markets are those in which GMAC and its equivalents have greater than usual market shares. These captive lenders may react differently than banks to monetary policy shocks.

${ }^{12}$ These studies calculate concentration at the country level, which is likely to be inappropriate for some EU countries (Group of Ten, 2001, pages 268-270).
} 
not find significant effects from differences in market concentration. However, they define markets to be national in scope.

\section{Empirical Application}

Monetary policy can influence the rest of the economy through several channels. The monetary (or interest rate) channel refers to the effect of changes in the short-term interest rates determined by central bank policy on other interest rates and, through those rates, on spending and borrowing decisions of firms and households. A tightening of monetary policy results in a decline in bank reserves and, hence, the money supply. Interest rates rise to equilibrate money demand and supply and arbitrage transmits the change in interest rates to markets for other financial assets.

By contrast, the bank-lending channel focuses on monetary policy's effect on bank lending, in addition to its influence over interest rates generally. The bank-lending channel recognizes that loan and bond financing are not perfect substitutes for a subset of firms that includes most small businesses. A tightening of monetary policy causes a reduction in deposits, which reduces banks' loanable funds. If imperfect markets make it difficult (or more costly) for banks to attract wholesale funds to replace lost deposits, banks will reduce lending and increase loan interest rates. ${ }^{13}$ This will reduce the supply of credit to borrowers who are dependent on bank credit because information asymmetries close off their access to other credit markets. One important market imperfection is the degree to which a market deviates from perfect competition and an atomistic structure.

We assume that monetary policy shifts banks' marginal costs by affecting the interest rates they must pay at the margin for loanable funds. In other words, banks do not face a perfectly elastic demand for their open market liabilities. ${ }^{14}$ We use the federal funds rate as our policy variable, since it is the rate at which banks can obtain wholesale funds and has been used in much of the previous research on monetary policy. In the standard model of the firm, the adjustment of prices and output is a function of the

\footnotetext{
${ }^{13}$ Lending from more liquid institutions is less susceptible to fluctuations in monetary policy, since these institutions can sell securities to cover reserves. See Kashyap and Stein (2000).

${ }^{14}$ This condition for the existence of the bank lending channel is discussed in Kashyap and Stein (1994). See also Bernanke and Gertler (1995).
} 
curvature of demand and cost functions and of market competition. ${ }^{15}$ Specifically, in the case of perfect competition where equilibrium price is set to marginal costs, changes in marginal costs are fully reflected in the price. As the degree of competition decreases, two opposing theoretical possibilities exist. In the first case, as the degree of competition decreases, output becomes less sensitive to changes in marginal costs and price changes in response to marginal cost shocks become muted; as a result, the sensitivity of bank lending to the federal funds rate decreases as the market becomes less competitive. In the second case, under certain demand and cost curvature conditions, price becomes more sensitive to changes in marginal costs as the degree of competition decreases. Vives (1999) discusses the more general conditions for such "overshifting" to occur. ${ }^{16}$ Empirical work in banking supports the first theoretical case in virtually every study in which competition is found to have a significant effect on prices or output.

We consider a reduced-form model of bank lending, where we interact market concentration with the federal funds rate to model the effect of market structure on monetary policy. We begin from a standard, static model of the relationship between loan quantity and loan price, structural variables and variables included to control for possible differences in loan demand across markets:

(1) $\mathrm{L}_{\mathrm{mt}}=\beta_{1}$ fedfunds $_{\mathrm{t}}+\beta_{2} \mathrm{HHI}_{\mathrm{mt}}+\beta_{3} \mathrm{HHI}_{\mathrm{mt}} *$ fedfunds $_{\mathrm{t}}+\Sigma \varphi_{\mathrm{imt}} \mathrm{Z}_{\mathrm{imt}}+\lambda *$ trend $_{\mathrm{t}}+$ $\sum \alpha_{\mathrm{m}}$ Market $_{\mathrm{m}}+\varepsilon_{\mathrm{mt}}$

where $\mathrm{L}_{\mathrm{mt}}$ is the dollar volume of loans originated in market $\mathrm{m}$ at time $\mathrm{t}$, fedfunds $\mathrm{s}_{\mathrm{t}}$ is the average federal funds rate for period $\mathrm{t}, \mathrm{HHI}_{\mathrm{mt}}$ is a measure of market concentration, and $\mathrm{Z}_{\mathrm{mt}}$ is a vector of I market-specific variables that control for cross-sectional differences in demand. The model also includes market dummy variables to capture cross-sectional differences not controlled by $\mathrm{Z}$ and a time trend to control for the general increase in loan

\footnotetext{
15 The literature on tax incidence and exchange rate pass-through discusses these issues in more detail. See Vives (1999) and Goldberg and Knetter (1997).

${ }^{16}$ Freixas and Rochet (1998) describe a model of banking where "overshifting" occurs under the assumption of constant elasticity of demand and a symmetric Cournot equilibrium.
} 
volume over the sample period. Note that in (1), the overall effect of a change in the federal funds rate on lending is $\left(\beta_{1}+\beta_{3} \mathrm{HHI}\right){ }^{17}$

Estimation of (1) is problematic for at least two reasons. First, the dependent variable is almost certainly nonstationary. Second, the marginal effects implied by the equation are implausible for any cross-section of markets that vary substantially in size: the effect of a change in the federal funds rate will have a much greater effect on loan volume in a large market than in a small market. For these reasons, and because policymakers are often more interested in the effects of changes in monetary policy than in the effect of a certain level of policy tightness or ease, we transform (1) by taking the percentage change in the dependent and explanatory variables to yield:

(2) $\Delta \ln \mathrm{L}_{\mathrm{mt}}=\gamma_{1} \Delta$ lnfedfunds $\mathrm{t}_{\mathrm{t}}+\gamma_{2} \Delta \operatorname{lnHHI} \mathrm{mt}_{\mathrm{m}}+\gamma_{3} \operatorname{lnHHI}_{\mathrm{m}, \mathrm{t}-1} * \Delta \operatorname{lnfedfunds}_{\mathrm{t}}+$

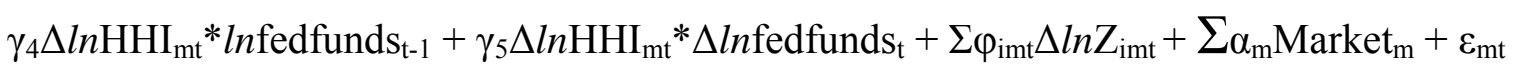

Equation (2) relates the percentage change in loan volume to the percentage change in the cost of loanable funds, the change in market structure, the three interactions of market structure and federal funds rate that come from differencing and normalizing (1), and the change in control variables. The time trend drops out of the differenced equation. Market dummies are retained in the model because it is likely that there continue to be idiosyncratic market effects on the percentage change in loans over time that are not captured by structural or control variables.

The coefficients of greatest interest are $\gamma_{1}$ through $\gamma_{5}$. We expect an increase in the federal funds rate to reduce the volume of bank lending, so that $\gamma_{1}+\gamma_{3} \ln \mathrm{HHI}_{\mathrm{m}, \mathrm{t}-1}+$ $\gamma_{5} \Delta l n \mathrm{HHI}_{\mathrm{mt}}$ should be negative. We expect banks in markets with a less competitive structure to lend less than banks in more competitive markets, ceteris paribus, so that $\gamma_{3} \Delta$ Infedfunds $\mathrm{s}_{\mathrm{t}}$ would be less than zero. We would also expect that an increase in concentration would lead to less lending, so that $\gamma_{2}+\gamma_{4} \operatorname{lnfedfunds}_{\mathrm{t}-1}+\gamma_{5} \Delta$ lnfedfunds $_{\mathrm{t}}$ should be negative. However, structure tends to change very slowly over time, so the

\footnotetext{
${ }^{17}$ A model could be estimated with loan price or margin as the dependent variable rather than loan volume, but the only loan price data available for a large cross-section of banks are imputed prices calculated from Call Report data. These prices are constructed by dividing revenue from a category of loans by average loan volume, and are notoriously inaccurate.
} 
effect on lending of the percentage change in structure over one year may very well be insignificant.

Other explanatory variables are included as controls for possible loan demand effects. Percentage changes in market income, local employment and market population are used to control for cyclical economic differences at the market level that affect the demand for bank lending. It is expected that these variables will have positive coefficients. However, like market structure, these demographic variables tend to change slowly over time, so there effects may be insignificant when (2) is estimated.

\section{$\underline{\text { Data }}$}

CRA data have been collected annually since 1996. Our data set consists of the count and dollar volume of business loans originated from year-end 1996 to year-end 2002. CRA data are reported in two ways. The first captures all small loans -- defined as those under $\$ 1$ million dollars -- to businesses, regardless of the size of the business, while the second captures all small loans to small businesses. In both cases, the data measure lending to firms that generally do not have access to other external means of funding. ${ }^{18}$ These data are collected at the census-tract level, so that aggregation to the local market level is easily accomplished. ${ }^{19}$ We consider the volume of loans originated in each market as the dependent variable. ${ }^{20}$

The CRA data on small loans to all businesses separate lending into three size categories and give the dollar value of originations in each category: loans under $\$ 100,000$; loans greater than $\$ 100,000$, but under $\$ 250,000$; and loans greater than $\$ 250,000$ (but under $\$ 1$ million). There is no such size breakdown for the second CRA database on loans to businesses with less than $\$ 1$ million in annual revenue. However, given the small size of the borrowers, it is likely that most such loans would be in the smallest size category.

In addition to total small business loans, we consider the subset of loans from $\$ 100,000$ to $\$ 1$ million in size. We exclude loans less than $\$ 100,000$ because the

\footnotetext{
${ }^{18}$ There is some potential measurement error in the first set of CRA data, however, since it could include small loans made to large firms that have access to other external funding methods.

${ }^{19}$ Aggregation to the market level removes the need to adjust the data for the effect of mergers.

${ }^{20}$ As a robustness check, we also use the number of loans originated as the dependent variable.
} 
majority of these loans appear to represent small business credit card loans. Over 50 percent of the loans of less than $\$ 100,000$ have an average origination amount of less than $\$ 10,000$. The number of loans in this category has increased throughout the sample period, and the average origination amount has declined. It is our assumption that these loans differ dramatically from loans greater than $\$ 100,000$ in both the interest rate charged and in the dynamics of the interest rate relative to changes in monetary policy. However, without substantially more data on the loans (such as price and customer information), we cannot confirm this hypothesis. ${ }^{21}$

The CRA data are limited in two ways. First, loan originations greater than $\$ 1$ million are not included in the data. While these large loans may be important for measuring total lending, they are not vital to our analysis. Firms that are able to obtain very large loans also are more likely to have access to other sources of credit. Second, banks that are not part of a bank holding company and have less than $\$ 250$ million in assets are not required to file CRA reports. However, such small independent banks make up a relatively small percentage of all small business lending. ${ }^{22}$

We aggregate all CRA loan measures to the market level to calculate our dependent variables. Those markets with the most extreme reported dependent variable values are dropped from the sample to eliminate outliers and errors. Specifically, we eliminate the top and bottom 5 percent of observations for each year. The end result is a six-year panel dataset with approximately 14,070 observations. ${ }^{23}$

Concentration data are derived from the FDIC's Summary of Deposits (SOD) database. We use the Herfindahl-Hirshman index (HHI), which is defined as the sum of

\footnotetext{
${ }^{21} \mathrm{We}$ estimate regressions in which the dependent variable is either the dollar volume or the number of loans with balances less than $\$ 100,000$. The results from these estimations differ greatly from regressions on larger loans.

${ }^{22}$ Banks required to file CRA reports provided 66 percent of all small business loans and 68 percent of the dollar amount of such loans in 1996, figures that rise to 75 percent of the number of loans and 84 percent of the dollar amount of loans in 2001. Inclusion of market dummy variables in the estimated models should help to control for differences in coverage across markets. We also estimate (2) using an alternative dependent variable that attempts to include loans by those firms that are not required to file CRA reports. The dollar volume of loans originated by such firms is estimated using Call Report data on outstanding loans. Results using this alternative dependent variable are qualitatively the same as those reported in the text.

${ }^{23}$ We have a slightly smaller sample of 11,687 observations for loans to businesses with less than $\$ 1$ million in revenue, since this variable is collected starting in 1997. We also estimate the model including the extreme observations. These results are reported below.
} 
the squared deposit market shares, as our concentration measure. ${ }^{24}$ Following convention, and in line with previous research that has found geographic banking markets to be best approximated by economically integrated local areas, urban markets are defined as Metropolitan Statistical Areas (MSAs), and rural markets as counties. ${ }^{25}$

Federal funds rates are annual averages of daily rates. By averaging, we are able to account for whether changes in the federal funds rate occurred relatively early or relatively late in the year covered by one of our observations. Annual employment data are from the Bureau of Labor Statistics, while market population and income data are from Bureau of Economic Analysis estimates. Means, standard deviations, minima and maxima of all variables are given in table 1 for the full sample, urban markets and rural markets.

\section{Preliminary Univariate Results}

Before presenting estimates of (2), we conduct a simple, univariate analysis to demonstrate that increases in market concentration tend to reduce the adjustments of bank portfolios to outside stimuli. For this analysis, we construct a sample of single market banks, i.e. those institutions that book 100 percent of their deposits to a single market. ${ }^{26}$ Call Reports for these institutions yield the firms' total loans, commercial and industrial (C\&I) loans, consumer loans, real estate loans and securities. ${ }^{27}$ The resulting data set has 469,082 quarterly observations from 1990 to 2003. Use of Call Report data allows us to extend our analysis beyond the time period covered by our regression analysis.

We calculate Pearson correlation coefficients between quarterly changes in each of the balance sheet measures and market concentration. The results are in table 2 . While all of the correlations are small in magnitude, in all cases but one the correlation coefficient between either the percentage change in securities or the percentage change in

\footnotetext{
${ }^{24}$ We measure market shares in percentage terms, so that the HHI reaches a maximum of 10,000 in a monopolized market (100 percent squared) and approaches 0 in a market with an atomistic structure. This is the way in which HHI is normally presented by antitrust authorities, but HHI can also be measured ranging from 1 to 0 . Rescaling $\mathrm{HHI}$ affects the size of $\gamma_{1}$ and $\gamma_{3}$, but has no effect on the other coefficients. ${ }^{25}$ Geographic market definitions are based on the 1999 definitions of metropolitan areas and are kept constant throughout the sample period.

${ }^{26}$ Data on market-specific deposit totals come from the annual SOD report. We assume that an institution that operates in a single market in the SOD in any one year is a single-market institution for all four quarters in that year.

${ }^{27}$ See Kashyap and Stein (2000) for a discussion on the calculation of bank securities from the Call Report.
} 
a loan variable and market concentration is negative and significant at the 1 percent level. The final correlation, between concentration and the change in consumer loans, is insignificant. These results indicate that volatility in securities and loans outstanding decreases as market concentration increases.

This simple analysis does not take into account all factors considered in regression analysis. However, those factors omitted from the analysis would likely strengthen the conclusion that adjustments in bank lending to changes in the federal funds rate are lower in concentrated markets than in unconcentrated markets. For example, rural banking markets tend to be more concentrated than urban markets, and rural markets tend to be populated by smaller borrowers and lenders that have less access to alternative sources of credit from money markets than do firms in larger, less concentrated markets. This would tend to cause larger portfolio in changes in rural markets over time, an effect that is more than offset in this univariate analysis.

Additional results suggest that the effects of concentration on bank behavior do not appear to be proxies for the effects of bank-level data examined in previous research. While the correlation coefficients between the market HHI and both levels and changes in bank liquidity, bank capital and bank size are significant, in no case is the absolute value of these correlations greater than 0.07 .

\section{$\underline{\text { Regression Results }}$}

We estimated several versions of equation (2) using ordinary least squares over our entire sample and rural and urban subsamples with three different measures of loan volume. Estimation of this equation presents colinearity problems, however, because $\Delta l n \mathrm{HHI}_{\mathrm{mt}}$ and $\Delta l n \mathrm{HHI}_{\mathrm{mt}}{ }^{*} \operatorname{lnfedfunds}_{\mathrm{t}-1}$ have a Pearson correlation coefficient of 0.996 on our full sample of markets, a result that is not unexpected given that the federal funds rate is the same for all markets in any one year and there is only limited variation in the federal funds rate over the seven years of our sample period. Estimation results for (2) are included in the appendix, but the colinearity causes some instability in the coefficient estimates. Tables 3 through 5 show estimation results dropping the interaction term

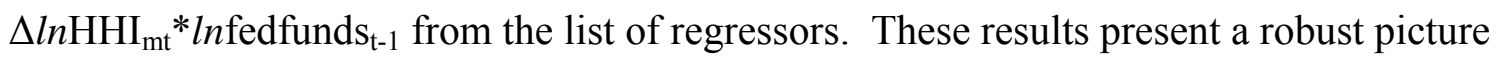
of the effect of monetary policy on bank lending (through the monetary and bank-lending 
channels) and the effect of competition on the bank-lending channel. ${ }^{28}$ Table 3 shows results using the dollar volume of loan originations as the dependent variable for all local banking markets. Three different sets of loans are examined: all CRA loans, all such loans greater than $\$ 100,000$, and all CRA loans to small businesses. Results are presented with the variables controlling for differences in market demand included, though exclusion of these variables has little effect on the core results. Results are generally consistent across the three regressions reported in table $3 \mathrm{a}$.

Table $3 \mathrm{~b}$ shows the effects of a 1 percent change in the federal funds rate for the three regressions at sample means for the dependent variables and at three other levels of the HHI. This table demonstrates the effect of differences in the level of local market concentration on the strength of the effect of a change in the monetary policy instrument. The first row of table $3 \mathrm{~b}$ gives the effect of a change of 1 percent in the federal funds rate on lending $\left(\gamma_{1}+\gamma_{3} l n \mathrm{HHI}_{\mathrm{m}, \mathrm{t}-1}+\gamma_{5} \Delta l n H H \mathrm{II}_{\mathrm{mt}}\right)$, evaluated at the sample means for market concentration and the change in concentration. ${ }^{29}$ The remaining three rows of table $3 \mathrm{~b}$ compute the effect of a federal funds rate change at three other levels of the HHI. The first two values, 1000 and 1800, are used because, according to policy guidelines used by the Department of Justice and other federal agencies, markets are considered to be moderately concentrated at an HHI of 1000 and highly concentrated at 1800 . The final value of 3500 approximates the mean concentration level for rural markets. ${ }^{30}$

In all cases, an increase in the federal funds rate has the expected negative effect on the volume of bank lending. The effect is largest when the dependent variable is restricted to loans larger than $\$ 100,000$ and smallest in the regression on small loans to small businesses. Because the marginal effect of concentration on the response of lending to monetary policy is positive (i.e., increases in concentration reduce the negative effect of an increase in the federal funds rate on lending), policy has a much larger overall effect when the HHI is at 1000 , near the lower end of the sample distribution, than

\footnotetext{
${ }^{28}$ We are unable to identify the effects from the monetary or bank lending channels separately through the coefficient estimate on the federal funds rate. However, $\gamma_{3}$ and the results given in tables $3 b, 4 b$ and $5 b$ measure a portion of the bank-lending channel that can be attributed to market imperfections due to lessthan-perfect competition.

${ }^{29}$ The mean level of market concentration is 3226 .

${ }^{30}$ In all cases, the change in the HHI is kept at its sample mean. The mean and standard deviation for this variable are so small that allowing their values to vary within reasonable bounds would affect the numbers in table $3 \mathrm{~b}$ by only about 0.001 .
} 
when it is at the mean level for rural banking markets. ${ }^{31}$ The response of all CRA loans and all loans greater than $\$ 100,000$ to a change in the federal funds rate is almost 50 percent greater at an HHI level of 1000 than in more concentrated markets with an HHI of 3500 . In the regression on small loans to small businesses, the effect of an increase in the federal funds rate is essentially zero in concentrated markets.

The level of market concentration and the change in that level have the expected negative effects on loan volumes in all three regressions, but the effects are small. A 1 percent increase in the HHI lowers lending by approximately 0.01 percent in regressions on all CRA loans and loans greater than $\$ 100,000$; the effect is slightly larger in the regression on small loans to small businesses. ${ }^{32}$ Similarly, an increase in the rate of increase of the HHI has a small, negative effect on bank lending. A 1 percent increase in the annual change in concentration reduces the annual change in lending by from 0.07 to 0.12 percent. $^{33}$

The three control variables have insignificant coefficients in most cases. Dropping these variables from the regression has no qualitative effect on the results reported for the three variables of primary interest. The 2,571 market dummies are jointly very significant.

We split our sample into two subsamples in order to check for differences in the bank-lending and structural results between rural and urban markets. Tables 4 and 5 show the results for these sets of regressions using our three measures of the dollar volume of loan originations as the dependent variables. We find that our results are much more robust in rural markets (table 4a), where the coefficients of interest have the same signs and roughly the same magnitudes as in the regressions on the full sample. The coefficient on the second interaction term is less significant than in the overall sample, but the overall sensitivity of the effectiveness of monetary policy to changes in local market structure is very similar to that for the overall sample (see table $4 \mathrm{~b}$ ). The effects

\footnotetext{
${ }^{31}$ This marginal effect is just the derivative of $\left(\gamma_{1}+\gamma_{3} \ln \mathrm{HHI}_{\mathrm{m}, \mathrm{t}-1}+\gamma_{5} \Delta \ln \mathrm{HHI}_{\mathrm{mt}}\right)$ with respect to $\ln \mathrm{HHI}$, or $\gamma_{3}$.

${ }^{32}$ This effect, measured by $\gamma_{3}{ }^{*} \Delta$ Infedfunds $_{\mathrm{t}}$, is -0.0096 in the regression on all CRA loans, -0.012 in the regression on loans over $\$ 100,000$ and -0.026 in the regression on small loans to small businesses. $\gamma_{3}$ is significant at the 1 percent level in the first and third cases and at the 5 percent level in the second case.

${ }^{33}$ This effect, measured by $\gamma_{2}+\gamma_{5} * \Delta$ Infedfunds $_{\mathrm{t}}$, is -0.073 in the regression on all CRA loans, -0.118 in the regression on loans over $\$ 100,000$ and -0.065 in the regression on small loans to small businesses. This effect is significant at the 10 percent level in the regression on all CRA loans, at the 5 percent level in the regression on loans over $\$ 100,000$, and is insignificant in the third regression.
} 
of concentration and changes in concentration are negative in all cases and similar in magnitude to those for the full sample. ${ }^{34}$

Results for urban markets tend to be weaker (table 5). In all cases, a tightening of monetary policy through an increase in the federal funds rate leads to a decrease in the volume of small business lending (table 5b), with magnitudes evaluated at sample means similar to those for rural markets. However, because the marginal effect of an increase in concentration on the change in the effectiveness of monetary policy, as measured by $\gamma_{3}$, has an unexpected negative sign in all three regressions of table $5 \mathrm{a}$, the effectiveness of monetary policy is greater in less concentrated markets than in more concentrated markets. This result may be due to the generally low and less variable concentration levels in urban markets. The average concentration in such markets is below the level at which the Federal Reserve and other antitrust regulators consider market structure to be highly concentrated. ${ }^{35}$ Another possible cause of these results is a greater access to external financing among borrowers and lenders in urban markets than among their rural counterparts.

Kashyap and Stein (2000) and Jayaratne and Morgan (2000) find that the banklending channel is strongest in rural counties and among smaller banks. We find little difference in the significance or strength of the monetary channel between urban and rural markets: effects are significant in both subsamples and are of similar magnitudes. However, like previous research, we find that any structural dampening of the effects of changes in monetary policy through the bank-lending channel appears to be limited to rural markets.

Numerous variations on the basic model were estimated to test its robustness. Dropping the three variables added to control for differences in market demand has no

\footnotetext{
${ }^{34}$ The overall effect of a 1 percent change in the level of concentration is -0.012 in the regression on all CRA loans, -0.013 in the regression on loans over $\$ 100,000$ and -0.028 in the regression on small loans to small businesses. All of these effects are statistically significant at the 1 or 5 percent levels. The effect of a 1 percent change in the rate of change in concentration is -0.104 in the regression on all CRA loans, -0.156 in the regression on loans over $\$ 100,000$ and -0.064 in the regression on small loans to small businesses. The first effect is statistically significant at the 1 percent level and the second at the 5 percent level, while the third is insignificant.

${ }^{35}$ The average HHI in urban markets is 1500 . The Federal Reserve does not consider a market highly concentrated unless the HHI is 1800 or more.
} 
effect on the signs or significance level of any of the variables of primary interest. Including those observations with the most extreme values for the dependent variable makes no qualitative difference in the coefficients for the change in the federal funds rate or the HHI, but it decreases the significance of some of the interaction terms.

We estimated the model using the total number of loan originations as the dependent variable rather than loan dollar volume. These results are less consistent than those for loan volume. In the regression using all CRA loans as the dependent variable, the coefficient on the percentage change in the federal funds rate has the unexpected positive sign and is highly significant. The marginal effect of a change in the federal funds rate is positive, because of this coefficient estimate. This result can be explained by the large number of loans of less than $\$ 100,000$, which represent a small share of the total origination amount, but a much larger share of the number of loans. The positive marginal effect is likely due to the strong increase in the number of loans of less than $\$ 100,000$ over the sample period in a falling federal funds rate environment. This increase can be attributed to the rapid spread of new loan products - for example, small business credit cards. In the other two regressions, however, the effect of a change in the federal funds rate has the expected effect. None of the structural effects are significant in the regressions on the number of loans. Thus, we find strong evidence to support the monetary channel using either the dollar volume or the number of small business loans, but evidence in favor of a reduced effect in more concentrated markets through the banklending channel comes only from regressions on loan dollar volume.

We explored three alternatives to the deposit-based HHI as a measure of market structure. Previous research has relied on deposit-based measures of market structure because of the incompleteness of alternative data for local markets, such as the exclusion of some small banks from the CRA database mentioned in the Data section.

Nevertheless, because the focus of this study is on CRA lending, we constructed three concentration measures using available CRA data. The first is an HHI index including all reported CRA loans in a market, while the second includes all CRA loans of more than $\$ 100,000$, thereby excluding the rapidly increasing number of small loans, many of which are likely to be credit card loans. Finally, we construct an HHI index including all reported CRA loans in the market and including estimates of the dollar volumes of loans 
originated by banks not required to report CRA data. ${ }^{36}$ Use of any of these alternatives has little effect on the existence of the bank-lending channel in our data. However, the differing HHI measures tend to reduce the marginal effect of competition on the banklending channel. The coefficients for the percentage change in the federal funds rate are similar to those in the estimation using deposit HHIs. Use of these CRA-based HHI measures does not change the signs of the coefficients on the interaction terms, but it reduces the magnitude of these coefficients. However, these results indicate a much larger negative marginal effect of the percentage change of the HHI on the percentage change in lending, since the coefficient on this variable is negative and larger in magnitude in almost all of these regressions.

The relationship between the effectiveness of monetary policy and competition in the banking industry may be of particular policy interest to the Federal Reserve since it both conducts monetary policy and enforces antitrust policy in banking. The main task of the Federal Reserve is to administer monetary policy, with the primary goals of maintaining stable prices and full employment. However, it is also charged with numerous bank regulatory responsibilities, including antitrust enforcement. The Bank Holding Company Act (1956) and the Bank Merger Act (1960) charge the Federal Reserve with upholding federal antitrust laws in banking and financial markets. ${ }^{37}$

If greater market concentration merely reduced the effectiveness of monetary policy across the board, policy makers could simply increase changes in the federal funds rate in order to offset the muting effects of the loss of competition. However, that is not always possible. As interest rates affected by monetary policy near the zero bound, policymakers' ability to make significant changes in rates is limited. In addition, changes in competition through large mergers or merger waves in the banking industry may introduce additional uncertainty about the effectiveness of monetary policy. Finally, our analysis shows that the effectiveness of monetary policy varies across markets with

\footnotetext{
${ }^{36}$ Estimates for CRA non-reporters are computed using Call Report data on loans outstanding. These loan figures are multiplied by 0.6 to reflect the ratio of loans originated to loans outstanding in the U.S. as a whole. For those non-reporters that operate in more than one local banking market, loans are allocated among markets in proportion to the banks' deposits.

${ }^{37}$ The 1963 Philadelphia National Bank decision by the Supreme Court upheld the Federal Reserve's responsibility in merger cases. The decision also validated the use of the Clayton Antitrust Act (1914) in banking. The Federal Reserve shares antitrust responsibilities for the banking industry with the Department of Justice, the Federal Deposit Insurance Corporation, and the Office of the Comptroller of the Currency.
} 
differing levels of concentration. There are significant differences in changes in lending in response to changes in the federal funds rate between concentrated rural markets and unconcentrated urban markets. ${ }^{38}$ Our results show that monetary policy has a greater effect on the real economy in unconcentrated markets rather than in concentrated markets.

\section{Conclusion}

This paper combines research on the existence and importance of the banklending channel of monetary policy in the United States with research on the relationship between banking market structure and the stickiness of bank deposit and lending rates in order to examine the effect of differences in concentration of local banking markets on the bank-lending channel of monetary policy. We use the dollar volume of U.S. bank loans from CRA data to estimate a reduced-form model. These data are more accurate measures of lending activity in the U.S. than the data on changes in the level of outstanding loans used in previous research. We are able to affirm the existence of the bank-lending channel effect in rural markets, but find that results are weaker in urban markets, as reported by some previous research. Moreover, we find that the impact of the bank-lending channel is weaker as markets become more concentrated. This relationship between the effectiveness of monetary policy and market structure has not, to our knowledge, been explored previously.

\footnotetext{
${ }^{38}$ Most rural markets are concentrated and most urban markets are unconcentrated.
} 


\section{References}

Amel, Dean F. and Martha Starr-McCluer (2002), "Market Definition in Banking: Recent Evidence," The Antitrust Bulletin, 47(1), pp. 63-89.

Altunbas, Yener, Fazylov, Otabek, and Molyneux, Philip (2002) “Evidence on the Bank Lending Channel in Europe," Journal of Banking and Finance, 26(11), pp. 2093-2110.

Bernanke, Ben S., and Alan S. Blinder (1988), "Credit, Money, and Aggregate Demand," American Economic Review, 78(2), pp. 435-39.

Bernanke, Ben S., and Alan S. Blinder (1992), "The Federal Funds Rate and the Channels of Monetary Transmission,” American Economic Review, 82(4), pp. 901-21.

Bernanke, Ben and Mark Gertler (1995), "Inside the Black Box: The Credit Channel of Monetary Policy Transmission," Journal of Economic Perspectives, 9(4), pp.27-48.

Bernanke, B., M. Gertler and S. Gilchrist (1999), "The Financial Accelerator in a Quantitative Business Cycle Framework," in J. Taylor and M. Woodford, eds., Handbook of Macroeconomics, Volume 1c (North Holland: New York).

Bikker, Jacob A., and Haaf, Katharina (2002) "Competition, Concentration, and Their Relationship: An Empirical Analysis of the Banking Industry," Journal of Banking and Finance, 26(11), pp. 2191-2214.

Cecchetti, Stephen G. (1995), "Distinguishing Theories of the Monetary Transmission Mechanism.” Federal Reserve Bank of St. Louis Review, 77(3), pp. 83-97

Cecchetti, Stephen G. (1999), "Legal Structure, Financial Structure, and the Monetary Policy Transmission Mechanism," Federal Reserve Bank of New York Economic Policy Review, 5(2), pp. 9-28. 
Corvoisier, Sandrine, and Gropp, Reint (2002) "Bank Concentration and Retail Interest Rates," Journal of Banking and Finance, 26(11), pp. 2155-2189.

Cottarelli, Carlo, and Angeliki Kourelis (1994), "Financial Structure, Lending Rates, and the Transmission Mechanism of Monetary Policy," International Monetary Fund Staff Papers, 41(4), pp. 587-623.

Freixas, Xavier, and Jean-Charles Rochet (1998), MicroEconomics of Banking (The MIT Press: Cambridge, Massachusetts).

Group of Ten (2001), Report on Consolidation in the Financial Sector (Bank for International Settlements: Basel, Switzerland).

Goldberg, Pinelopi K. and Knetter, Michael M. (1997) "Goods Prices and Exchange Rates: What Have We Learned?" Journal of Economic Literature, 35, pp. 1243-1272.

Hannan, Timothy H., and Allen N. Berger (1991), "The Rigidity of Prices: Evidence from the Banking Industry," American Economic Review, 81(4), pp. 938-945.

Jayaratne, Jith, and Donald P. Morgan (2000), "Capital Market Frictions and Deposit Constraints at Banks," Journal of Money, Credit, and Banking, 32(1), pp. 74-92.

Kahn, Charles, George Pennacchi and Ben Sopranzetti (2001), "Bank Consolidation and Consumer Loan Interest Rates," in Consumer Transactions and Credit, proceedings of a conference sponsored by the Federal Reserve Bank of Philadelphia and Wharton Financial Institutions Center.

Kakes, Jan, and Sturm, Jan-Egbert (2002), "Monetary Policy and Bank Lending: Evidence from German Banking Groups," Journal of Banking and Finance, 26(11), pp. 2077-2092. 
Kashyap, Anil K., and Jeremy C. Stein (1994), "Monetary Policy and Bank Lending," in N. Gregory Mankiw, ed., Monetary Policy. (University of Chicago Press for NBER:

Chicago), pp.221-56.

Kashyap, Anil K., and Jeremy C. Stein (1997), “The Role of Banks in Monetary Policy: A Survey with Implications for the European Monetary Union,” Federal Reserve Bank of Chicago Economic Perspectives, September-October, pp. 2-18.

Kashyap, Anil K., and Jeremy C. Stein (2000), "What Do a Million Observations on Banks Say About the Transmission of Monetary Policy?” American Economic Review, 90(3), pp. 407-428.

Kashyap, Anil K., Jeremy C. Stein and David W. Wilcox (1993), "Monetary Policy and Credit Conditions: Evidence from the Composition of External Finance," American Economic Review, 83(1), pp.78-98.

Klein, M. (1971), “A Theory of the Banking Firm,” Journal of Money, Credit, and Banking, 3, pp. 205-218.

Kwast, Myron L., Martha Starr-McCluer and John D. Wolken (1997), "Market Definition and the Analysis of Antitrust in Banking," The Antitrust Bulletin, 42(4), pp. 973-95.

Lensink, Robert, and Sterken, Elmer (2002), "Monetary Transmission and Bank Competition in the EMU," Journal of Banking and Finance, 26(11), pp. 2065-75.

Mester, Loretta J, and Anthony Saunders (1995), “When Does the Prime Rate Change?" Journal of Banking and Finance, 19(5), pp. 743-764.

Monti, M. (1972), "Deposit, Credit, and Interest Rate Determination under Alternative Bank Objectives," in G.P. Szego and K. Shell, eds., Mathematical Models in Investment and Finance (North-Holland: Amsterdam). 
Neumark, David, and Steven A. Sharpe (1992), "Market Structure and the Nature of Price Rigidity: Evidence from the Market for Consumer Deposits," Quarterly Journal of Economics, 107(2), pp. 657-680.

Peltzman, Sam (1969), "The Banking Structure and the Transmission of Monetary Policy," Journal of Finance, 24(3), pp. 387-411.

Romer, Christina, and David Romer (1990), "New Evidence on the Monetary Transmission Mechanism," Brookings Papers on Economic Activity, 1, pp. 149-214.

Sellon, Gordon H., Jr. (2002), “The Changing U.S. Financial System: Some Implications for the Monetary Transmission Mechanism," Federal Reserve Bank of Kansas City Economic Review, 87(1), pp. 5-35.

Stein, Jeremy C. (1998), "An Adverse Selection Model of Bank Asset and Liability Management with Implications for the Transmission of Monetary Policy,” Rand Journal of Economics, 29(3), pp.466-486.

The Small Business Economy. A Report to the President (2001) (The United States Government Printing Office: Washington, D.C.).

Vives, Xavier (1999), Oligopoly Pricing: Old Ideas and New Tools (The MIT Press: Cambridge, Massachusetts). 


\section{Table 1 - Descriptive Statistics}

\section{(a) All markets}

\begin{tabular}{|c|c|c|c|c|}
\hline Variable & Mean & $\begin{array}{l}\text { Standard } \\
\text { Deviation }\end{array}$ & Minimum & Maximum \\
\hline Total Loan Volume & 78,468 & 332,134 & 5 & $8,132,503$ \\
\hline$\Delta \ln$ Total Loan Volume & 0.14 & 0.21 & -0.038 & 1.49 \\
\hline Number of Loans & 1,861 & 8,745 & 1 & 288,970 \\
\hline$\Delta \ln$ Number of Loans & 0.22 & 0.25 & -0.57 & 1.05 \\
\hline Volume of Loans $>\$ 100 \mathrm{k}$ & 62,320 & 250,253 & 101 & $6,238,090$ \\
\hline$\Delta \ln$ Volume of Loans $>\$ 100 \mathrm{k}$ & 0.12 & 0.47 & -1.15 & 1.560 \\
\hline Number of Loans $>\$ 100 \mathrm{k}$ & 187 & 706 & 1 & 16,981 \\
\hline$\Delta \ln$ Number of Loans $>\$ 100 \mathrm{k}$ & 0.11 & 0.41 & -0.92 & 1.39 \\
\hline $\begin{array}{l}\text { Loan Volume to Firms with }<\$ 1 \\
\text { million in Revenue }\end{array}$ & 37,598 & 135,573 & 5 & $3,174,155$ \\
\hline $\begin{array}{l}\Delta \ln \text { Loan Volume to Firms with }< \\
\$ 1 \text { million in Revenue }\end{array}$ & 0.15 & 0.44 & -0.96 & 1.76 \\
\hline$\Delta \ln F e d$ funds rate & -0.19 & 0.36 & -0.85 & 0.23 \\
\hline HHI & 3226 & 2060 & 377 & 10,000 \\
\hline$\Delta \ln \mathrm{HHI}_{\mathrm{t}}$ & -0.002 & 0.08 & -1.19 & 1.62 \\
\hline$\Delta \ln$ Population & 0.004 & 0.02 & -0.11 & 0.21 \\
\hline$\Delta \operatorname{lnLocal}$ Employment & 0.01 & 0.04 & -0.79 & 0.37 \\
\hline$\Delta \ln$ Market Income & 0.04 & 0.04 & -1.40 & 0.48 \\
\hline
\end{tabular}


(b) Rural markets

\begin{tabular}{|c|c|c|c|c|}
\hline Variable & Mean & $\begin{array}{l}\text { Standard } \\
\text { Deviation }\end{array}$ & Minimum & Maximum \\
\hline Total Loan Volume & 14,402 & 21,546 & 5 & 267,992 \\
\hline$\Delta \ln$ Total Loan Volume & 0.15 & 0.42 & -1.06 & 1.57 \\
\hline Number of Loans & 366 & 4299 & 1 & 6,703 \\
\hline$\Delta \ln N u m b e r$ of Loans & 0.23 & 0.26 & -0.60 & 1.09 \\
\hline Volume of Loans $>\$ 100 \mathrm{k}$ & 10,683 & 15,874 & 101 & 204,129 \\
\hline$\Delta \ln$ Volume of Loans $>\$ 100 \mathrm{k}$ & 0.12 & 0.543 & -1.286 & 1.67 \\
\hline Number of Loans $>\$ 100 \mathrm{k}$ & 35 & 52 & 1 & 6144 \\
\hline$\Delta \ln N$ umber of Loans $>\$ 100 \mathrm{k}$ & 0.11 & 0.45 & -1.05 & 1.39 \\
\hline $\begin{array}{l}\text { Loan Volume to Firms with }<\$ 1 \\
\text { million in Revenue }\end{array}$ & 8,879 & 13,463 & 5 & 167,221 \\
\hline $\begin{array}{l}\Delta \ln \text { Loan Volume to Firms with }< \\
\text { \$1million in Revenue }\end{array}$ & 0.15 & 0.48 & -1.02 & 1.85 \\
\hline$\Delta \operatorname{lnFed}$ funds rate & -0.19 & 0.36 & -0.85 & 0.23 \\
\hline HHI & 3514 & 2088 & 684 & 10,000 \\
\hline$\Delta \operatorname{lnHHI} \mathrm{H}_{\mathrm{t}}$ & -0.003 & 0.08 & -1.19 & 1.62 \\
\hline$\Delta \ln$ Population & 0.004 & 0.02 & -0.11 & 0.21 \\
\hline$\Delta I n$ Local Employment & 0.01 & 0.04 & -0.79 & 0.37 \\
\hline$\Delta \ln$ Market Income & 0.04 & 0.05 & -1.40 & 0.48 \\
\hline
\end{tabular}




\section{(c) Urban markets}

\begin{tabular}{|c|c|c|c|c|}
\hline Variable & Mean & $\begin{array}{l}\text { Standard } \\
\text { Deviation }\end{array}$ & Minimum & Maximum \\
\hline Total Loan Volume & 518,505 & 814,757 & 13,393 & $8,132,503$ \\
\hline$\Delta \ln$ Total Loan Volume & 0.09 & 0.15 & -0.25 & 0.53 \\
\hline Number of Loans & 12,185 & 422,260 & 184 & 288,970 \\
\hline$\Delta \ln N$ umber of Loans & 0.18 & 0.17 & -0.20 & 0.72 \\
\hline Volume of Loans $>\$ 100 \mathrm{k}$ & 365,517 & 575,747 & 10,290 & $6,238,090$ \\
\hline$\Delta \ln$ Volume of Loans $>\$ 100 \mathrm{k}$ & 0.09 & 0.19 & -0.36 & 0.67 \\
\hline Number of Loans $>\$ 100 \mathrm{k}$ & 1067 & 1598 & 26 & 16,981 \\
\hline$\Delta \ln$ Number of Loans $>\$ 100 \mathrm{k}$ & 0.08 & 0.18 & -0.37 & 0.65 \\
\hline $\begin{array}{l}\text { Loan Volume to Firms with }<\$ 1 \\
\text { million in Revenue }\end{array}$ & 234,046 & 320,405 & 9671 & $3,174,155$ \\
\hline $\begin{array}{l}\Delta \ln \text { Loan Volume to Firms with }< \\
\$ 1 \text { million in Revenue }\end{array}$ & 0.10 & 0.18 & -0.35 & 0.64 \\
\hline$\Delta \ln F e d$ funds rate & -0.06 & 0.23 & -0.47 & 0.23 \\
\hline HHI & 1484 & 607 & 38 & 7761 \\
\hline$\Delta \ln \mathrm{HHI}_{\mathrm{t}}$ & 0.002 & 0.12 & -0.91 & 1.13 \\
\hline$\Delta \ln$ Population & 0.01 & 0.01 & -0.07 & 0.06 \\
\hline$\Delta \operatorname{lnLocal}$ Employment & 0.01 & 0.02 & -0.16 & 0.10 \\
\hline$\Delta \ln$ Market Income & 0.05 & 0.03 & -0.08 & 0.22 \\
\hline
\end{tabular}


Table 2- Pearson Correlation Coefficients Using Call Report Data for Single-Market Banks

\begin{tabular}{ll} 
Variable & HHI \\
\hline$\Delta \ln$ Securities & $-0.011^{* * *}$ \\
$\Delta \ln$ Total Loans & $-0.060^{* * *}$ \\
$\Delta \ln$ C\&I Loans & $-0.006^{* * *}$ \\
$\Delta \ln$ Real estate loans & $-0.017^{* * *}$ \\
$\Delta \ln$ Consumer Loans & 0.002
\end{tabular}

Note: $* * *$-- Significant at the 1 percent level. 
Table 3a - Regression Results for the Full Sample

\begin{tabular}{|c|c|c|c|}
\hline Variable & All loans & Loans $>\$ 100,000$ & Loans to Small Businesses \\
\hline$\Delta$ Infedfunds & $\begin{array}{l}-0.506^{* * *} \\
(0.13)\end{array}$ & $\begin{array}{l}-0.643^{* * * *} \\
(0.18)\end{array}$ & $\begin{array}{l}-0.906^{* * *} \\
(0.16)\end{array}$ \\
\hline$\Delta \operatorname{lnHHI}$ & $\begin{array}{l}-0.022 \\
(0.04)\end{array}$ & $\begin{array}{l}-0.066 \\
(9.15)\end{array}$ & $\begin{array}{c}0.007 \\
(0.06)\end{array}$ \\
\hline $\ln \mathrm{HHI}^{*} \Delta \operatorname{lnfedfunds}$ & $\begin{array}{l}0.0495 * * * \\
(0.02)\end{array}$ & $\begin{array}{l}0.059^{* *} \\
(0.02)\end{array}$ & $\begin{array}{l}0.111^{* * * *} \\
(0.02)\end{array}$ \\
\hline$\Delta \operatorname{lnHHI} * \Delta \operatorname{lnfedfunds}$ & $\begin{array}{l}0.265^{* *} \\
(0.12)\end{array}$ & $\begin{array}{l}0.261^{*} \\
(0.16)\end{array}$ & $\begin{array}{l}0.303^{* *} \\
(0.15)\end{array}$ \\
\hline$\Delta \ln$ Employment & $\begin{array}{l}-0.124 \\
(0.12)\end{array}$ & $\begin{array}{c}0.002 \\
(0.17)\end{array}$ & $\begin{array}{c}0.009 \\
(0.15)\end{array}$ \\
\hline$\Delta$ InIncome & $\begin{array}{c}0.148 \\
(0.10)\end{array}$ & $\begin{array}{r}0.201 \\
(0.16)\end{array}$ & $\begin{array}{l}0.246^{* *} \\
(0.12)\end{array}$ \\
\hline$\Delta \ln$ Population & $\begin{array}{r}0.196 \\
(0.37)\end{array}$ & $\begin{array}{l}-0.125 \\
(0.56)\end{array}$ & $\begin{array}{r}0.789 \\
(0.50)\end{array}$ \\
\hline No. of observations & 14069 & 12265 & 11696 \\
\hline $\mathrm{R}^{2}$ & 0.17 & 0.18 & 0.18 \\
\hline
\end{tabular}

Table 3b - Percent Change in Lending as a Result of a 1 Percent Change in the Federal Funds Rate

All loans Loans $>\mathbf{\$ 1 0 0 , 0 0 0}$ Loans to small businesses

$\begin{array}{llll}\text { HHI }=\text { sample mean } & -0.115^{* * *} & -0.179 * * * & -0.029 * * \\ \mathrm{HHI}=1000 & -0.165^{* * *} & -0.234^{* * *} & -0.140^{* * *} \\ \mathrm{HHI}=1800 & -0.136^{* * *} & -0.199^{* * *} & -0.075^{* * *} \\ \mathrm{HHI}=3500 & -0.103^{* * *} & -0.160^{* * *} & -0.001\end{array}$

Notes: Standard errors in parentheses

*** -- Significant at the 1 percent level

** -- Significant at the 5 percent level

* -- Significant at the 10 percent level 


\section{Table 4a - Regression Results for Rural Markets Only}

\begin{tabular}{|c|c|c|c|}
\hline Variable & All loans & Loans $>\$ 100,000$ & $\begin{array}{c}\text { Loans to Small } \\
\text { Businesses }\end{array}$ \\
\hline$\Delta$ Infedfunds & $\begin{array}{l}-0.606 * * * \\
(0.17)\end{array}$ & $\begin{array}{l}-0.666^{* * *} \\
(0.25)\end{array}$ & $\begin{array}{l}-0.958 * * * \\
(0.20)\end{array}$ \\
\hline$\Delta \operatorname{lnHHI}$ & $\begin{array}{l}-0.065 \\
(0.06)\end{array}$ & $\begin{array}{l}-0.101 \\
(0.09)\end{array}$ & $\begin{array}{c}0.018 \\
(0.08)\end{array}$ \\
\hline $\ln \mathrm{HHI}^{*} \Delta \operatorname{lnfedfunds}$ & $\begin{array}{l}0.061^{* * *} \\
(0.02)\end{array}$ & $\begin{array}{l}0.062^{* *} \\
(0.03)\end{array}$ & $\begin{array}{l}0.118^{* * *} \\
(0.03)\end{array}$ \\
\hline$\Delta \operatorname{lnHHI} * \Delta \operatorname{lnfedfunds}$ & $\begin{array}{r}0.205 \\
(0.16)\end{array}$ & $\begin{array}{r}0.269 \\
(0.21)\end{array}$ & $\begin{array}{l}0.345^{*} \\
(0.19)\end{array}$ \\
\hline$\Delta \operatorname{lnEmployment}$ & $\begin{array}{l}-0.103 \\
(0.13)\end{array}$ & $\begin{array}{l}-0.058 \\
(0.20)\end{array}$ & $\begin{array}{c}0.018 \\
(0.17)\end{array}$ \\
\hline$\Delta \operatorname{lnIncome}$ & $\begin{array}{r}0.265 \\
(0.11)\end{array}$ & $\begin{array}{c}0.244 \\
(0.18)\end{array}$ & $\begin{array}{l}0.303^{* *} \\
(0.14)\end{array}$ \\
\hline$\Delta \ln$ Population & $\begin{array}{r}0.110 \\
(0.42)\end{array}$ & $\begin{array}{l}-0.225 \\
(0.63)\end{array}$ & $\begin{array}{l}1.205^{* *} \\
(0.55 \\
)\end{array}$ \\
\hline No. of observations & 12329 & 10528 & 10249 \\
\hline $\mathrm{R}^{2}$ & 0.16 & 0.17 & 0.18 \\
\hline
\end{tabular}

Table $4 b$ - Percent Change in Lending as a Result of a 1 Percent Change in the Federal Funds Rate

\begin{tabular}{rrrc} 
& \multicolumn{1}{c}{ All loans } & Loans $>\mathbf{\$ 1 0 0 , 0 0 0}$ & Loans to small businesses \\
HHI $=$ sample mean & $-0.117 * * *$ & $-0.174 * * *$ & -0.013 \\
$\mathrm{HHI}=1000$ & $-0.185^{* * *}$ & $-0.239 * * *$ & $-0.144 * * *$ \\
$\mathrm{HHI}=1800$ & $-0.149 * * *$ & $-0.202 * * *$ & $-0.075 * * *$ \\
$\mathrm{HHI}=3500$ & $-0.109 * * *$ & $-0.161 * * *$ & 0.004
\end{tabular}

Notes: Standard errors in parentheses.

*** -- Significant at the 1 percent level.

** -- Significant at the 5 percent level.

* -- Significant at the 10 percent level. 
Table 5a - Regression Results for Urban Markets Only

\begin{tabular}{lccc} 
Variable & All loans & Loans $>\$ 100,000$ & $\begin{array}{c}\text { Loans to Small } \\
\text { Businesses }\end{array}$ \\
\hline$\Delta$ Infedfunds & 0.244 & 0.276 & $0.587^{* *}$ \\
& $(0.20)$ & $(0.25)$ & $(0.26)$ \\
$\Delta$ InHHI $_{\mathrm{t}}$ & -0.018 & 0.013 & 0.065 \\
InHHI*$^{*}$ Infedfunds & $(0.04)$ & $(0.04)$ & $(0.06)$ \\
& $-0.053^{*}$ & $-0.063^{*}$ & $-0.101^{* * *}$ \\
$\Delta$ InHHI*AInfedfunds & $(0.03)$ & $(0.03)$ & $(0.36)$ \\
& $0.181^{*}$ & $0.282^{* * *}$ & $0.325^{* * *}$ \\
$\Delta$ InEmployment & $(0.09)$ & $(0.11)$ & $(0.12)$ \\
& -0.110 & 0.338 & $0.941^{* *}$ \\
$\Delta$ InIncome & $(0.30)$ & $(0.38)$ & $(0.42)$ \\
& $-0.524^{* *}$ & $-1.007^{* * *}$ & -0.365 \\
$\Delta$ InPopulation & $(0.21)$ & $(0.27)$ & $(0.29)$ \\
& $1.525^{*}$ & $1.978^{*}$ & -1.701 \\
No. of observations & $(0.86)$ & $(1.08)$ & $(1.24)$ \\
$\mathrm{R}^{2}$ & 1743 & 1743 & 1452 \\
& 0.25 & 0.26 & 0.20
\end{tabular}

Table $5 b$ - Percent Change in Lending as a Result of a 1 Percent Change in the Federal Funds Rate

All loans Loans $>\$ \mathbf{1 0 0 , 0 0 0} \quad$ Loans to small businesses

\begin{tabular}{|c|c|c|c|}
\hline $\mathrm{HHI}=$ sample mean & $-0.139 * * *$ & $-0.178 * * *$ & $-0.143 * * *$ \\
\hline $\mathrm{HHI}=1000$ & $-0.122 * * *$ & $-0.158 * * *$ & $-0.110 * * *$ \\
\hline $\mathrm{HHI}=1800$ & $-0.153 * * *$ & $-0.195 * * *$ & $-0.170 * * *$ \\
\hline $\mathrm{HHI}=3500$ & $-0.188 * * *$ & $-0.237 * * *$ & $-0.237 * * *$ \\
\hline
\end{tabular}

Notes: Standard errors in parentheses.

*** -- Significant at the 1 percent level.

** -- Significant at the 5 percent level.

* -- Significant at the 10 percent level. 


\section{Appendix}

Table A3 - Regression Results of Equation (2) the Full Sample

\begin{tabular}{|c|c|c|c|}
\hline Variable & All loans & Loans $>\$ 100,000$ & Loans to Small Businesses \\
\hline$\Delta$ Infedfunds & $\begin{array}{l}-0.504 * * * \\
(0.13)\end{array}$ & $\begin{array}{l}-0.641^{* * * *} \\
(0.18)\end{array}$ & $\begin{array}{l}-0.905^{* * *} \\
(0.16)\end{array}$ \\
\hline$\Delta \operatorname{lnHHI}$ & $\begin{array}{l}1.070^{*} \\
(0.55)\end{array}$ & $\begin{array}{l}1.806^{* *} \\
(0.72)\end{array}$ & $\begin{array}{l}1.313^{* *} \\
(0.66)\end{array}$ \\
\hline $\ln \mathrm{HHI}^{*} \Delta \operatorname{lnfedfunds}$ & $\begin{array}{l}0.484 * * * \\
(0.02)\end{array}$ & $\begin{array}{l}0.0590^{* *} \\
(0.02)\end{array}$ & $\begin{array}{l}0.110^{* * *} \\
(0.02)\end{array}$ \\
\hline$\Delta \ln \mathrm{HHI}^{*} \operatorname{lnfedfunds}$ & $\begin{array}{l}-0.652^{*} \\
(0.33)\end{array}$ & $\begin{array}{l}-1.117^{* * *} \\
(0.43)\end{array}$ & $\begin{array}{l}-0.778^{* *} \\
(0.39)\end{array}$ \\
\hline$\Delta \operatorname{lnHHI} * \Delta \operatorname{lnfedfunds}$ & $\begin{array}{l}0.374 * * * \\
(0.13)\end{array}$ & $\begin{array}{l}0.455^{* * *} \\
(0.17)\end{array}$ & $\begin{array}{l}0.436^{* * * *} \\
(0.16)\end{array}$ \\
\hline$\Delta \ln$ Employment & $\begin{array}{l}-0.119 \\
(0.12)\end{array}$ & $\begin{array}{c}0.0129 \\
(0.17)\end{array}$ & $\begin{array}{c}0.0144 \\
(0.15)\end{array}$ \\
\hline$\Delta \operatorname{lnIncome}$ & $\begin{array}{r}0.147 \\
(0.10)\end{array}$ & $\begin{array}{c}0.199 \\
(0.16)\end{array}$ & $\begin{array}{c}0.244 \\
(0.12)\end{array}$ \\
\hline$\Delta \ln$ Population & $\begin{array}{c}0.204 \\
(0.37)\end{array}$ & $\begin{array}{l}-0.119 \\
(0.56)\end{array}$ & $\begin{array}{c}0.808 \\
(0.50)\end{array}$ \\
\hline No. of observations & 14069 & 12265 & 11696 \\
\hline $\mathrm{R}^{2}$ & 0.17 & 0.18 & 0.18 \\
\hline
\end{tabular}

Notes: Standard errors in parentheses.

*** -- Significant at the 1 percent level.

** -- Significant at the 5 percent level.

* -- Significant at the 10 percent level. 
Table A4 - Regression Results of Equation (2) for Rural Markets

\begin{tabular}{|c|c|c|c|}
\hline Variable & All loans & Loans $>\$ 100,000$ & $\begin{array}{l}\text { Loans to Small } \\
\text { Businesses }\end{array}$ \\
\hline$\Delta \operatorname{lnfedfunds}$ & $\begin{array}{l}-0.608 * * * \\
(0.17)\end{array}$ & $\begin{array}{l}-0.670 * * * \\
(0.25)\end{array}$ & $\begin{array}{l}-0.960 * * * \\
(0.20)\end{array}$ \\
\hline$\Delta \operatorname{lnHHI}$ & $\begin{array}{r}0.897 \\
(0.72)\end{array}$ & $\begin{array}{l}1.717 * \\
(0.97)\end{array}$ & $\begin{array}{r}0.953 \\
(0.85)\end{array}$ \\
\hline $\ln \mathrm{HHI}^{*} \Delta \ln$ fedfunds & $\begin{array}{l}0.611 \text { *** } \\
(0.02)\end{array}$ & $\begin{array}{l}0.0628^{* *} \\
(0.03)\end{array}$ & $\begin{array}{l}0.118^{* * *} \\
(0.03)\end{array}$ \\
\hline$\Delta \ln \mathrm{HHI}^{*} \ln$ fedfunds & $\begin{array}{l}-0.575 \\
(0.43)\end{array}$ & $\begin{array}{l}-1.085^{*} \\
(0.58)\end{array}$ & $\begin{array}{l}-0.557 \\
(0.50)\end{array}$ \\
\hline$\Delta \operatorname{lnHHI} * \Delta \operatorname{lnfedfunds}$ & $\begin{array}{c}0.285^{*} \\
(0.17)\end{array}$ & $\begin{array}{l}0.429 * \\
(0.23)\end{array}$ & $\begin{array}{l}0.423 * * \\
(0.20)\end{array}$ \\
\hline$\Delta \operatorname{lnEmployment}$ & $\begin{array}{l}-0.0998 \\
(0.13)\end{array}$ & $\begin{array}{l}-0.0496 \\
(0.20)\end{array}$ & $\begin{array}{l}0.0208 \\
(0.17)\end{array}$ \\
\hline$\Delta \operatorname{lnIncome}$ & $\begin{array}{l}0.265^{* *} \\
(0.11)\end{array}$ & $\begin{array}{c}0.241 \\
(0.18)\end{array}$ & $\begin{array}{l}0.302 * * \\
(0.14)\end{array}$ \\
\hline$\Delta \ln$ Population & $\begin{array}{r}0.117 \\
(0.42)\end{array}$ & $\begin{array}{l}-0.217 \\
(0.63)\end{array}$ & $\begin{array}{l}1.219^{* *} \\
(0.55)\end{array}$ \\
\hline No. of observations & 12329 & 10528 & 10249 \\
\hline $\mathrm{R}^{2}$ & 0.16 & 0.17 & 0.18 \\
\hline
\end{tabular}

Notes: Standard errors in parentheses.

*** -- Significant at the 1 percent level.

** -- Significant at the 5 percent level.

* -- Significant at the 10 percent level. 
Table A5 - Regression Results of Equation (2) for Urban Markets

\begin{tabular}{|c|c|c|c|}
\hline Variable & All loans & Loans $>\$ 100,000$ & $\begin{array}{c}\text { Loans to Small } \\
\text { Businesses }\end{array}$ \\
\hline$\overline{\Delta l n f e d f u n d s}$ & $\begin{array}{r}0.227 \\
(0.20)\end{array}$ & $\begin{array}{c}0.246 \\
(0.25)\end{array}$ & $\begin{array}{l}0.544^{* *} \\
(0.26)\end{array}$ \\
\hline$\Delta \ln \mathrm{HHI}_{\mathrm{t}}$ & $\begin{array}{l}0.960 * * \\
(0.42)\end{array}$ & $\begin{array}{l}1.284^{* *} \\
(0.51)\end{array}$ & $\begin{array}{l}2.128^{* * *} \\
(0.54)\end{array}$ \\
\hline $\ln \mathrm{HHI}^{*} \Delta \operatorname{lnfedfunds}$ & $\begin{array}{l}-0.0501 * \\
(0.03)\end{array}$ & $\begin{array}{l}-0.0589 * \\
(0.03)\end{array}$ & $\begin{array}{l}-0.0940 * * * \\
(0.04)\end{array}$ \\
\hline$\Delta \ln \mathrm{HHI}^{*} \operatorname{lnfedfunds}$ & $\begin{array}{l}-0.582 * * \\
(0.25)\end{array}$ & $\begin{array}{l}-0.756^{* *} \\
(0.30)\end{array}$ & $\begin{array}{l}-1.223^{* * *} \\
(0.32)\end{array}$ \\
\hline$\Delta \operatorname{lnHHI} * \Delta \operatorname{lnfedfunds}$ & $\begin{array}{l}0.291 * * * \\
(0.10)\end{array}$ & $\begin{array}{l}0.450 * * * \\
(0.13)\end{array}$ & $\begin{array}{l}0.601 * * * \\
(0.14)\end{array}$ \\
\hline$\Delta \ln$ Employment & $\begin{array}{l}-0.101 * * \\
(0.30)\end{array}$ & $\begin{array}{c}0.354 \\
(0.38)\end{array}$ & $\begin{array}{l}0.970 * * \\
(0.41)\end{array}$ \\
\hline$\Delta \ln$ Income & $\begin{array}{l}-0.533 * * \\
(0.21)\end{array}$ & $\begin{array}{l}-1.023 * * * \\
(0.27)\end{array}$ & $\begin{array}{l}-0.404 \\
(0.29)\end{array}$ \\
\hline$\Delta \ln$ Population & $\begin{array}{l}1.567 * \\
(0.86)\end{array}$ & $\begin{array}{l}2.019 * * \\
(1.08)\end{array}$ & $\begin{array}{l}-1.591 \\
(1.23)\end{array}$ \\
\hline No. of observations & 1743 & 1743 & 1452 \\
\hline $\mathrm{R}^{2}$ & 0.26 & 0.26 & 0.21 \\
\hline
\end{tabular}

Notes: Standard errors in parentheses.

*** -- Significant at the 1 percent level.

** -- Significant at the 5 percent level.

* -- Significant at the 10 percent level. 